\title{
Hungarian Ministry of the Interior and its Civil Servants in the Post-war Turmoil*
}

\author{
Julia Bavouzet
}

After the fall of the Habsburg Monarchy, Hungary experienced a transition from a multinational empire to a reduced, ethnically almost homogeneous entity. Between 1918 and 1920, it also saw the rise and fall of a democratic republic, a communist Soviet republic (communism's most spectacular success among the successor states), a Red and a White Terror, and finally a monarchist restoration in the form of a regency. Thus, contrary to other successor states celebrating their independence and the achievement of a national state, Hungary suffered from defeat, political chaos, foreign occupation, and insecurity about the fate of the nation.

Yet despite the post-war turmoil, great political and social transformations occurred during these years, that reflected in public administration. In these times of trouble, the Ministry of the Interior, which was in charge of the administration, was faced with specific issues, and the difficulties of the situation led to three major challenges ${ }^{1}$. The first and most fundamental of these was to guarantee the continuous functioning of the administration amidst the political turmoil, relying on the old guard of ministerial Konzeptsbeamten (fogalmazói tisztviseló) and on former bureaucratic norms and practices "surviving the successive collapse of the constitutional laws"3. Yet the second challenge

* This paper is published in: Hofratsdämmerung? Verwaltung und ihr Personal in den Nachfolgestaaten der Habsburgermonarchie 1918 bis 1920, eds. Peter BECKER-Therese GARSTENAUER (forthcoming, Wien 2020).

${ }^{1}$ The present study does not address the specific issue of the liquidation of the former imperial common institutions and their administrative corps. Regarding this question, for Hungarian civil servants see Éva SOMOGYI, Hagyomány és átalakulás. Állam és bürokrácia a dualista Habsburg Monarchiában [Tradition and Transformation. State and Bureaucracy in the Dualist Habsburg Monarchy] (Budapest 2006) 254. As for the Austrians, see Therese GARSTENAUER, Diensteide und Gelöbnisse ehemaliger Bediensteter der Habsburgermonarchie 1918-1921, in: La question du serment. Le serment, de l'âge du Prince à l'ère des Nations, eds. Hervé BISMUTH-Friedrich TAUBERT (forthcoming, Heidelberg 2020).

${ }^{2}$ Like in Austria and Germany, Konzeptsbeamte stands for those civil servants who work in the Konzeptsdienst of the various ministries. They can be Concipist (fogalmazó, X.-IX. ranks), assisant secretary (segédtitkár, VIII. rank), secretary (titkár, VII. rank), departement councillor (osz̧tálytanácsos, VI. rank) and ministerial councillor (minisz̨teri tanácsos, V. rank), under the authority of state secretaries (államtitkár, III. rank) and ministers (miniszter, II.-I. ranks). Besides, Konzeptsbeamten are assisted by auxiliary corps (auxiliary office, accounting office) and for some ministries even by technical corps (financial Konzeptsdienst in the ministry of Finance, Kulturbeamten in the Agriculture), together with which they form the ministerial personal.

3 Théophile DucrocQ, Cours de droit administratif contenant l'exposé et le commentaire de la législation administrative dans son dernier état avec la reproduction des principaux textes, dans un ordre méthodique, 2 vol. (Paris ${ }^{5}$ 1877) 113. 
for each regime consisted in securing the loyalty of the administrative personnel, leading eventually to political purges. As for the third challenge, it mainly resulted from the economic crisis that followed the war: successive regimes had to face drastic cuts in the state's budget while reforming the administration, which led to massive reductions in administrative staff. Such Beamtenabbau was also to be observed in other European countries, but in Hungary it coincided with the massive arrival of refugee civil servants fleeing from detached territories and seeking posts in the administration.

Moreover, the change of regime ushered in by the Aster Revolution also presented the occasion, if not to make a clean slate of the former administration, at least to resolve some of its structural problems and dysfunctions. Overall administrative reform had indeed been repeatedly called for during the Dualist era, though without coming to a solution. Both republics thus improvised vast reform projects aiming at a renewal and democratization of the heavily criticized bureaucracy, manifesting their aspirations for an ideal society. Even if these projects could not be realized in such an unfavourable context, they deserve special attention as virtual possibilities that could have been - yet without falling into counterfactual history. The successive regimes indeed lacked the necessary time to carry out the planned reforms and failed at establishing the foundation of a new Hungarian state until the restoration of 1920.

This study aims to investigate the modalities of this great transformation that reshaped both the administrative structures and their personnel. What were the consequences of the fall of the monarchy and the revolutions for Hungarian public administration? How did the Ministry of the Interior face the political turmoil in terms of ruptures and continuity? Moreover, to what extent do radical situations such as war and revolutions allow the preparation of major reforms?

Centenarian commemorations of the revolutions and peace treaties may have ushered in a reviving of interest (mostly led by the research group Trianon 1004) about these troubled times, yet ministerial bureaucracy remains largely unknown. With the notable exceptions of the diplomatic and the officers corps ${ }^{5}$, both relying on rich archive material, state employees' situation in the postwar turmoil is still a blind spot in Hungarian historiography.

\footnotetext{
4 http://www.trianon100.hu/

${ }^{5}$ According to Pál Pritz, who studied the Hungarian Ministry of Foreign Affairs, leading officials of the People's Republic were recruited among former employees of the Ballhausplatz (61 out of 138 civil servants). This old guard remained in function until the end of the 1930's, yet bureaucratic routine and practices were reshaped by a new generation who set diplomacy on a new course. Pál PRITZ, Iratok a magyar külügyi szolgálat történetéhez, 1918-1945 [Documents to the History of Hungarian Foreign Affairs] (Budapest, 1994), and Magyar diplomácia a két háború között: tanulmányok [Hungarian Diplomacy Between the Two World Wars: Studies] (Budapest, 1995). On the contrary, the whole military elite remained in function after 1918: they served both republics ( $90 \%$ of them enrolled in
} 
The Ministry of the Interior during the People's Republic (October 31, 1918 - March 20, 1919)

After the Aster Revolution, the proclamation of the People's Republic (Magyar Népközztársaság), and the nomination of Mihály Károlyi's cabinet, the new Minister of the Interior Tivadar Batthyány, who served from October 31 to December 12, 1918, inherited a wartime bureaucracy. Like in other European countries, the exceptional conditions of the war had provoked profound modifications in the administration, extreme centralization, and drastic cuts to the budget ${ }^{6}$. Moreover, political demonstrations were forbidden, all communications placed under surveillance, and the press strictly censored. These measures meant the irruption of politics into public administration, which would continue to characterize its activities even in the post-war years. The Ministry of the Interior had thus become the first instrument of the government's politics well before the great transformation that occurred after the war.

In contrast with this, the revolution itself led only to minimal changes. The Ministry of the Interior happened to be one of those institutions whose prerogatives and duties remained nearly unaffected by the fall of the monarchy. The new regime inherited all jurisdictions, legal norms and bureaucratic practices which had progressively crystallized under Dualism ${ }^{7}$, thus guaranteeing administrative continuity - at least initially. Only the official designations were modified to make all references to the king, the crown, and the monarchy disappear ${ }^{8}$. The very paperwork reflects the material

the Red Army, following Aurél Stromfeld's example) as well as the conservatve restauration. Sándor SZAKÁLY, "A Magyarországi Tanácsköztársaság Vörös Hadseregének tisztikara [The Officer Corps of the Hungarian Soviet Republic’s Red Army]” Palócföld 1989/1 13-21, “A katonai elit Magyarországon 1919-1945 között [Military Elite in Hungary 1919-1945]” Korunk 2009/3 63-70.

${ }^{6}$ Since 1909 and the annexation of Bosnia-Hercegovina, which made war more probable than ever, the Ministry of the Interior had anticipated this wartime administration and prepared a hypothetical reorganization, eventually codified in Law 63/1912. It gave all executive power to the lord-lieutenants (föispán) (or, exceptionally, to the mayor in Budapest and to the governor in Fiume) and abrogated all dispositions regarding the autonomous administration of the counties and municipalities, as provided in Law 21/1888. Newly appointed government commissioners (kormánybiztos) were to oversee the police, border police forces, and gendarmerie; see János BOTOS, A Magyar királyi Belügyminisztérium a dualizmus korszakában [The Hungarian Royal Ministry of the Interior During the Dualist Era] (Budapest 1994) 8188.

${ }^{7}$ Julia BAVOUZET, Entre technocrates et administrateurs de l'Ancien Régime. Les hauts fonctionnaires des ministères hongrois du dualisme 1867-1918 (Diss. Université Paris-Nanterre 2017).

8 5430/1918 B[elügy] M[inisztérum] számú rendelet. Rendeletek Tára (1918) 2255. 
dimension of the transition': blue folders from previous regimes were reused, merely crossing out the mention of the former institutional designation, in accord with the prime minister's recommendation: There is no need to change the former coats of arms of the state, whether lesser, medium or greater, on available items that remain in use (sign boards, flags, seals, stamps, etc.). Only the royal crown is to be expunged from the armorial bearings by appropriate means (painting over, covering, erasing, crossing out, etc.). Arms on buildings or in works of art are not to be modified ${ }^{10}$.

As for the administrative elite who had served the monarchy and had been considered as the very pillar of the dynastic order, almost without exception they took the side of the new regime. Unlike the case of Germany, where the new chancellor Friedrich Ebert made a compromise with the former civil servants, explicitly asking them to remain at their posts and prevent the country from falling into chaos and famine, in exchange for the guarantee of full salaries and no dismissal for political reasons ${ }^{11}$, no such measure was needed in Hungary. The republic, relying on the old administrative elite's expertise to guarantee the continuity of the state, conducted no political purges $^{12}$ nor any ethnic purification ${ }^{13}$ - the central as well as county administrations were already fully magyarized, thanks to the magyarization politics initiated by Minister of the Interior Dezső Bánffy since the 1890 's. The only condition was to take the oath to the new regime ${ }^{14}-$ or to make

\footnotetext{
9 Similar crossouts also turn up in the Austrian state archives. See the contribution by Therese Garstenauer and Veronika Helfert in this volume.

10 5746/1918 M[iniszter] E[lnökség] számú rendelet. Rendeletek Tára (1918) 2293. Meglevő és még használatban álló tárgyakon (cimtáblákon, zászlókon, pecsétnyomókon, bélyegzőöön, dúcokon' stb.) az állam eddigi (kis, közép, nagy) címerét nem kell kicserélni, hamem csupán a cimpajzson nyugvó királyi koronát kell a címerböl megfelelö módon (átfestéssel, lefödéssel, lesimitással, véséssel stb.) eltávolítani. Beépitett címereket, müvészi alkotásokat nem kell átalakitani.

11 Marie-Bénédicte VINCENT, Serviteurs de l'État. Les élites administratives en Prusse de 1871 à 1933 (Histoire et société - Europes centrales, Paris 2006) 211s.

12 The Ministry of the Interior conducted no large-scale purge, yet the minutes of the Council of Ministers attest a deliberate policy of personnel exchange in various county administrations. See for example Minisztertanácsi jegyző́könyv (12. 11. 1918) pt. 1-21. All references to the minutes of the Council of Ministers are based on the digitizations available at http://adatbazisokonline.hu/adatbazis/minisztertanacsi-jegyzokonyvek-1867-1944 [4. 6. 2019].

${ }^{13}$ During the last month of the monarchy, the minister asked permission to dismiss 31 "foreign citizens" (külföldi állampolgárok) from the Ministry of the Interior, mostly minor civil servants, because they resided in Wien, Graz or Innsbruck. The Council of Ministers gave its assent: Minisztertanácsi jegyzőkönyv (31. 8. 1918) pt. 62. This measure, however, is to be seen as a cutting of bonds between the two halves of the empire rather than an ethnic purification. It had by no means the scale and the ambition of the ethnic purification led for example in German Austria, Slovenia, and Transylvania. See the contributions by Karl Megner and Guenther Steiner, by Rok Stergar, and by Judit Pál and Vlad Popovici in this volume.

14 The question of the oath is a major issue in Transylvania for example, not only for the former Hungarian civil servants but for the Romanian authorities as well. See the contribution by Judit Pál and Vlad Popovici in this volume.
} 
a solemn affirmation (fogadalom), a secularized form of oath which had already existed under Dualism $^{15}$. Throughout the country, public employees in the general administration, national security, and education - all of which were subordinate to the Ministry of the Interior - swore to be faithful to Hungary, to protect its complete independence, to serve with all [their] strength the Hungarian people, its freedom and its prosperity ${ }^{16}$. This new consensual formula avoided requiring them to break their former oath to the king and the monarchical constitution, to which they were formally still bound unlike German civil servants, who were released from their oath to the emperor ${ }^{17}$. Indeed, only the government was formally (by telephone) released from its oath by the king on 1 November, with a simple word that cancelled the pact biding Hungary to the Habsburg Empire ${ }^{18}$. It was only in December that a reference to the constitution and to the republican form of government was added

The distinction between oath and affirmation is also discussed in Austria. See the contribution by Therese Garstenauer and Veronika Helfert in this volume.

${ }_{15}$ People's Law 5/1918, S 9. All citations to Hungarian laws may be verified using the Wolters Kluwer online collection of laws, https://net.jogtar.hu/ [4 6. 2019]. Yet in practice, the situation proved to be more complex, as illustrated by the case of the diplomat György Barcza, who in 1918 was serving in the common Ministry of Foreign Affairs. Barcza steadfastly refused to take an oath to the Károlyi regime, yet in spite of his insubordination, he remained at his post, continuing to receive his salary and send his reports to Károlyi though his former superior, the Austrian minister Ludwig von Flotow; see György BARCZA, Diplomataemlékeim 1911-1945. Magyarország volt vatikáni és londoni követének emlékirataiból [My Memories as a Diplomat 1911-1945. From the Memoirs of the Former Ambassador in London and the Vatican], 2 vol. (Budapest 1994). This situation infringed the legal formalities but corresponded to the pragmatism of the Hungarian regime amidst the political chaos; see Julia BAVOUZET, Les usages du serment officiel des fonctionnaires hongrois de la Double Monarchie, in: La question du serment (cit. n. 1).

${ }^{16}$ Minisztertanácsi jegy rókö̈ny (2. 11. 1918) pt. 2. Én, N.N. esküszöm, hogy Magyarországhóz bü leszek, teljes függetlenségét megvédem, minden erömmel Magyarország népének javát, szabadságát és haladását fogom szolgálni. Isten engem úgy segéljen.

${ }^{17}$ This may also be compared to the case of German Austria, where it is not the emperor but a law, which released the civil servants from their oath (Gesetz vom 12. November 1918 über die Staats- und Regierungsform von Deutschösterreich. Staatsgesetzblatt 5 (1918), \6: Die Beamten, Offiziere und Soldaten sind des dem Kaiser geleisteten Treueides entbunden.)

18 This dramatic episode is related by Ernő Garami, appointed minister of the Commerce of the last royal ministry of October 1918, in his memoirs. Ernő GARAMI, Forrongó Magyarország: emlékezések és tanulságok [Revolution in Hungary: Memories and Lessons from the Past] (Budapest 1922) 37-40. The problematic question of the oath to the king also resurfaced as Charles IV made repeated attempts to recover the throne (first in March-April 1921 during the so-called Easter royal coup d'état, then again in October 1921). IV. Károly visszatérési kísérletei [Return Tentatives of Charles IV] (Budapest 1921)10, 23, 34. 
(to be faithful to the People's Republic and its constitution ${ }^{19}$ ) - yet the earlier formula continued to be used in various government offices ${ }^{20}$.

This structural continuity should not, however, blind us to the vast reforms intended by the new regime. Indeed, defeat was followed by a broad-based reconsideration of the bureaucratization process. Critiques of bureaucracy and cumbersome administrative procedures may be as old as bureaucracy itself, yet war provided a special occasion to question the state and its practices particularly in defeated countries ${ }^{21}$. In order to realize the democratization of Hungarian society, the government of the People's Republic has great expectations regarding the democratic and charitable spirit of the administration, and relies on it to defend the best interests of the people, as emphasized in a circular addressed to all civil servants by Zoltán Jánossy on November 21, 1918 ${ }^{22}$. In this letter, a sort of Hirtenbrief, the Secretary of State for the Interior called for change in the very behaviour of civil servants, as they ought to show warm concern and more interest in the face of the public, and to serve the interests of the people with their best intentions. References to "the people", in fact, became omnipresent in the official discourse, a source of legitimacy more comprehensible to contemporaries as the traditional ones the monarch, the constitution and the fatherland - had become more difficult to mobilize in the context of the moment. Moreover, beyond these moral declarations, the Minister of the Interior also announced an overall reform project for the administration ${ }^{23}$. Although widely advertised, details of it are not to be found in any People's Law nor in the Repertory of Ordinances (Rendeletek

\footnotetext{
19 155000/1918 B. M. számú rendelet. Rendeletek Tára (1918) 2432. Esküiszöm aź éló Istenre, hogy a Magyar Népköztársasághoz. és ennek alkotmányához bü lesz̨ek.

${ }^{20}$ For example, in March 1919, the newly appointed Mór Thierfield pronounced the former version of the official oath in the presence of Secretary of State Adolf Samassa: Hungarian National Archives Budapest (Magyar Nemzeti Levéltár Országos Levéltár) [MNL OL], K 148: Ministry of the Interior, 1920-5.t. 29-96 am/I, 3 old.

${ }^{21}$ In history, defeat has frequently acted as a catalyst for the rethinking of identity, state and nation. Indeed, consciousness of defeat compels a reconsideration and a renewal of thinking. The defeated must interrogate his defeat in order to surpass it, and beyond this experience, compose a new horizon of aspirations: Corine DEFRANCE-Catherine HOREL, Réalités, perceptions et usages de la défaite en Europe, in: Vaincus! Histoires de défaites. Europe, XIX $-\mathrm{XX}^{\mathrm{e}}$ siècles, eds. Corine DEFRANCECatherine HOREL-François-Xavier NERARD (Paris 2016) 9-25, 9-10.

22148607/1918 B. M. számú rendelet. Rendeletek. Tára (1918) 2409. A népköơtársaság kormánya a legnagyobb súlyt helyezi a körigazgatás demokratikus, emberszeretố szellemére és a népérdekek szempontjából való megbízhatóságára.

${ }^{23}$ Gyula MÉREI, A magyar októberi forradalom és a polgári pártok [The Hungarian October Revolution and the Bourgeois Parties] (Budapest 1969) 143-156, 164-168, 202.
} 
Tára). Only a few measures actually carried out allow us to take its measure, as the official declarations remained mostly ineffectual ${ }^{24}$.

In December, as the new regime stabilized, Jánossy committed himself to rationalizing and democratizing the county administration by abolishing the virilist system ${ }^{25}$ and applying the incompatibility principle in the county assemblies, which was eventually achieved by People's Laws 16/1919 and 17/1919. Reforms also took place in the central administration. A first major change occurred with the creation of a new Ministry of Work and Public Welfare (People's Law 4/1918), housed in the rooms of the former Ministry of Croatian Affairs ${ }^{26}$, into which three departments from the Ministry of the Interior were to be transferred - public health administration (Department $\mathrm{X})$, social care and welfare (XIII), and child protection (XV) ${ }^{27}$. Further restructuring was planned for March 1919, which would have completely reorganized the Ministry of the Interior: the remaining twelve departments were to be replaced by five "task groups" (szakecsoport), two of them dedicated to administration and three to police and law enforcement (see the lists in the Annex). Yet the People's Republic did not have the time to complete the planned restructuring, which the following regime would eventually reform once again.

Another step toward the democratization of the administration was made in January 1919, when the reorganization of the ministerial personnel led to a clean break with the former administrative status regime (státusærendęés). Every civil servant was newly appointed to their rank, thus resetting career advancement to the start. Equal pay for men and women, based on effective duties and not

${ }^{24}$ We can find the principles guiding the reform project outlined in Aurél HENCZ, Törekvések a közszolgálati etika kialakitására. A dualizmus és a két forradalom kora [The Way to a Public Service Ethic. The Dualist Era and the Two Revolutions], 2 vol. (Budapest 1987) 1 105-107.

25 Virilism refers to a political system based on Prussian model, in which the largest taxpayers, the virilists, are privileged ang get larger political (chiefly voting) rights, guaranteeing them a better representation. It was introduced in Hungary after the Compromise, and was finally abolished in 1929 in Budapest and after the Second World War in the county administration.

${ }^{26}$ Minisżtertanácsi jegyzőkönyv (4. 11. 1918) pt. 31.

27 6.625/1918 M. E. számú rendelet. Rendeletek. Tára (1919) 48. But in fact, the scheduled transfer did not occur before March 21, and the Ministry of the Interior continued as before to be responsible for public health. As for the new ministry, it was not an invention of the republic but the realization of a project initiated in 1917 (Law 11/1917), when count Tivadar Batthyány was appointed minister without portfolio. Neither the People's Republic nor the Soviet Republic, which took over the project, were able to fully realize it, and Zsigmond Kunfi thus remained a "minister without a ministry". It was only after 1920 that Ágost Benárd was appointed minister of "Public Welfare and Work" (Law 1/1920, \6), thus illustrating the continuity of social concern through the various changes of regime; see Tibor HAJDU, Az 1918-as magyarországi polgári demokratikus forradalom [The Bourgeois Democratic Revolution of 1918 in Hungary] (Budapest 1968) 75. 
on seniority or sex, was indeed one of the major reforms of the republic, so that "civil servants with equal qualification and equivalent duties would possibly be completely equal regarding their career advancement ${ }^{29}$ ". This did in fact break with past practices of the former ranking system, in which civil servants could be promoted only if a post became vacant, leading to random advancement. Yet despite ministerial councillor Kálmán Kerntler's efforts to elaborate the most rational status regime possible, the Association of Hungarian Civil Servants ${ }^{30}$ (Magyarországi Közalkalmazottak Szövetsége) registered many complains, leading to minor revisions in March. For example, state employees and junior officers opposed to the unification of their salary grid and pressed the government to provide for separate arrangements for technical and operational employees $^{31}$. Indeed, most of the oppositions these reforms may have encountered focus on the pragmatic dimension of the reorganization, but not its principle.

The reorganization of administrative personnel lasted until summer 1919 and was finally achieved by the Soviet Republic. The short time allotted to the five-month-long regime indeed prevented it from completing the reforms it had initiated. Besides, it had to confront another difficulty, namely the major post-war crisis the state was facing. Half-printed "white banknotes", inflation, and deep cuts to the state's budget characterized the financial difficulties amidst which the new regime had to demonstrate its effectiveness and ability to rule. An idea of the monetary situation under the Károlyi republic is afforded by the fact that the Ministry of the Interior's income was about 3,005,000 korona against 350,952,000 of expenses ${ }^{32}$ - the galloping inflation making it impossible to compare these figures with the previous regime's budget.

Moreover, the new regime found itself confronted with a demographic crisis, which for the administration manifested in the challenge of reintegrating demobilized civil servants returning from the front, who each had to be granted a post at least as well remunerated as when they were called to

\footnotetext{
${ }^{29}$ Minisztertanácsi jegyzókönyv (13. 1. 1919) pt. 14. Az 1. pont alatt emlitett mmegállapodások azon az alapon jöttek létre, hogy az egyenlö minösitésü és agyanaz̧ a munkört ellátó tisztviselök elömeneteli viszonyailehetöleg teljesen egyenlöek legyenek.

${ }^{30}$ Created on November 1918, the Association was actually the successor of the National Association of State Civil Servants (Állami Tisztviselók Orşágos Egyesülete) created in 1898, the National Association of Hungarian Civil Servants (Magyar Tisztviselók Országos Egyesülete, 1878) and the National Association of County Civil Servants (Vármegyei Tisztviselök Országos Egyesülete). These structures tried to coordinate the actions of the many smaller organisations, dedicated to special branches of the administartion (railways, posts, state employees) under the banner of a still nonexisting common status of "civil servant".

${ }^{31}$ Minisztertanácsi jegyzókönyv (17. 3. 1919) pt. 55.

32 János BOTOS, A Belügyminisztérium története a Monarchia széthullásátol a második világhboru végéig [History of the Ministry of the Interior from the Fall of the Monarchy to the End of the Second World War] (Budapest 1995) 7.
} 
war, taking advancement into account $t^{33}$. Indeed, the archives are filled with application letters from war veterans wishing to compensate the lost years by a promotion in the Ministry of the Interior ${ }^{34}$. Also, refugee civil servants fleeing Romanian occupation, starting in August 1916 but accelerating after December 1918, were seeking refuge in the central administration - a long-term process which became interwar Hungary's foremost social issue. Most of them were reactivated if they could furnish evidence of their former position as well as their professional qualification, provided they had not worked for or taken an oath ${ }^{35}$ to the successor states. This massive migration troubled the conduct of the administration. Week after week, the Home Affairs Bulletin (Belügyi Közlöny) continued to publish numerous announcements about "civil servants forced to leave their official duties as a result of extraordinary circumstances". Therefore, in a circular issued in order to secure the conduct of the administration, Minister of the Interior Vince Nagy (served January 25 to March $21,1919)$ urged his civil servants to deal only with the most pressing issues and take only provisional measures, effectively postponing the promised overall administrative reform ${ }^{36}$.

The People's Commissariat of the Interior during the Soviet Republic (March 21 - August 1, 1919)

On March 21, at the advent of the Hungarian Soviet Republic (Magyarországi Tanácsköztársaság), the People's Commissariat of the Interior led by Jenő Landler took over the duties and the personnel of the former ministry, ushering in a new period characterized by profound changes. Many officials as well as intellectuals involved themselves willingly in the new regime, mostly because it refused to accept the Vix Note regarding the line of demarcation between Hungary and Romania - a patriotic reason never disclaimed by Béla Kun's policies ${ }^{37}$. As soon as March 22, the Revolutionary Governing Council (Forradalmi Kormányzótanács) had to deal with the question of the loyalty of "reactionary" civil servants. To address the most urgent issue, Vice-Commissar for Justice István

\footnotetext{
33 6070/1918 M. E. számú rendelet. Rendeletek Tára (1918) 2303. Az elóléptetési viszonyok figyelembe vételével legalább is olyan javadalmazású állás biztosittassék, mint amilyenben hadbavonulásuk elött voltak.

${ }^{34}$ Julia BAvOUZET, Technocrats vs Politicians: Ministerial Konzeptsbeamten in the Afterwar Turmoil, (Belfast 4-7 April 2017).

35 Minisztertanácsi jegyzőkeönyv (17. 12. 1918) pt. 8.

36 153932/1918 B. M. számú rendelet. Rendeletek Tára (1918) 2450. Most csak ideiglenes megoldásról, átmeneti állapot teremtéséröl kell sürgösen gondoskodni, óhajtásaikat majd a végleges körigazgatási reform [...] során jutatthatják kifejezésre.

37 Botos, A Belügyminisztérium története (cit. n. 29) 17. Beside this patriotic dimension, it is true that many intellectuals were also attracted by the cultural reform project of the Soviet Republic. Judith SzAPOR, Hungarian Women's Activism in the Wake of the First World War. From Rights to Revanche (Bloomsbury 2017).
} 
Ládai proposed elaborating a new solemn declaration - a traditional oath appealing to God no longer being an option -, while Commissar Landler suggested requiring every civil servant to sign a formal written declaration; the latter was eventually adopted by the Governing Council ${ }^{38}$. Threeweek accelerated courses were also carried out in various government departments to give civil servants a socialist qualification and an education freed from bureaucratism ${ }^{39}$. Indeed, radical reform of both society and administration took the shape of an even sharper struggle against bureaucracy. On March 22, the official daily paper, the Red Newspaper (Vörös Újság), published an editorial entitled Down with Bureaucracy! (Le a bürokráciával.), describing administrative power as an "anti-class-war" element. The editorial called for shaking off the legal restraints and cumbersome procedures of a bureaucratic organization and giving way to revolutionary instinct and arbitrary violence in the conduct of affairs and justice ${ }^{40}$. It also announced, once again, an overall reorganization of the administration: From now on, all offices held by the dynasties will return into the hands of the proletariat, and finally the programme so long promised in every soapbox speech of past reformist politicians will be realized: the real simplification of the administration ${ }^{41}$.

Indeed, the new regime aimed at a renewal of administration and society at once, which was to eventually be achieved through a complete reconstruction of the state apparatus and the arrival of a new guard of civil servants recruited among proletarians. The major - and most urgent - task was to deconstruct the old county administration, a stronghold of the nobility, and to replace it with a system of councils. Yet the population often elected the old officeholders, and former county commissioners (alispán) and sheriffs (szolgabirô) remained in function, continuing for weeks to work within the framework of the county office ${ }^{42}$. Also, realizing the transformation with meagre means

\footnotetext{
38 Forradalmi Kormányzótanács jegyzókeönyv (22. 3. 1919) pt. 5; cited from Magda IMRE, A Forradalmi Kormányzótanács jegyzőkönyvei - 1919 [Protocols of the Revolutionary Governing Council - 1919] (Budapest 1986) 52.

39 12/1919 B[elügyi] N[épbiztosság] számú rendelete. Belügyi Közlöny 31 (6. 7. 1919) 1098. A belïgyi népbiztosság a

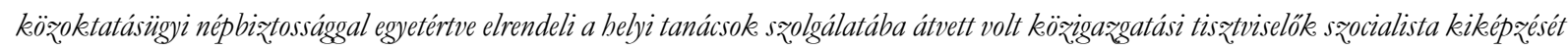
és bürokratizmustól mentes munkálkodásra való oktatását. Express training of civil servants was indeed a common trend in the successor states, whether for ideological reason as in Hungary or to ensure a minimal qualification for a new guard of national civil servants as, for example, in Romania; see the contribution by Judit Pál and Vlad Popovici in this volume.

${ }^{40}$ For many references to this problem in the economic field, see for example Tanácsok országos gyülésének naplója [Diary of the National Assembly of Councils] (16.6. 1919). For the judiciary, see Andrew C. JANOS, The Politics of Backwardness in Hungary 1825-1945 (Princeton 1982) 196s.

${ }^{41}$ Le a bürokráciával! [Down with Bureaucracy!] Vörös Újság 38 (22. 3. 1919) 3. Most a dinasztiák kezében levő állások proletárkézben kerülnek, és megavósul az a program, amely az elmultidökben minden kö̃igazgatási reformpolitikus kortesbeszédében belyett kapott: a körigazgatási igazi egyszurüsitése.

${ }^{42}$ BOTOS, A Belügyminisztérium története (cit. n. 29) 17.
} 
was a real challenge for the new regime and the local councils were difficult to coordinate, creating a great deal of work for the Commissariat of the Interior. It repeatedly had to urge the recalcitrant directorates (the permanent organs of the county councils) to apply the reforms, to realize the new policies, and to forbid arbitrary confiscations and other abuses. As late as May 1919, the Commissariat had to call the councils to order to make them finally abandon the old official titles: It still happens that some provincial councils, in their official correspondence, use the former designations of county commissioner, high sheriff (föszolgabíró), etc. This vocabulary has no place in the Soviet Republic, even if the council bas retained the former county commissioner, high sheriff, mayor (polgármester) or notary (jegyző) in service $^{43}$.

As for the central administration, the reorganization was less drastic but still reshaped both institutions and practices. In April 1919, the People's Commissariat of the Interior expanded its purview to oversee railways, navigation, and the inspection of river shipping, becoming the People's Commissariat of the Interior, Railways and Navigation ${ }^{44}$. An Investigative Department (Nyomoźó Osztály) was created, politically sensitive and composed of newly appointed officials, along with a department dedicated to the issue of refugee civil servants. Furthermore, a complete restructuring of the Interior was scheduled for August 1 (the very day the Soviet Republic fell), in order to rationalize and simplify the internal structure of the Commissariat. Like the previous one planned by the People's Republic, this reform would have abandoned the traditional departmental structure, replacing it by three major task groups (fócsoport), divided into 16 subgroups, yet carrying on the specialization of administrative branches as initiated since Dualism.

The Soviet Republic also introduced new administrative practices. As early as March 22, Béla Kun proposed abolishing the ranking system that had prevailed in the ministries since the 18th century, and replacing ranks and titles by a new kind of categorization (besorolás) ${ }^{45}$ : There will be no more such titles as, for example, secretary of state, ministerial councillor, or secretary, which define only the rank of the office. [...] Civil servants will be designated with terms that reflect their actual duties and their qualifications, for example: group leader, department leader, librarian, typist ${ }^{46}$. This meant the abolition of the traditional bureaucratic

\footnotetext{
43 355/1919 B. M. számú rendelete. Belügyi Közlöny 26 (1. 6. 1919) 998. Még mindig elöfordul, hogy egyes vidéki tanácsok bivatalos irataikban és felterjesztéseikben a régi hivatali elnevezések (alispán, föszolgabiró stb.) sz̧erepelnek. Ez a megjelölés a Tanácsköztársaságban helytelen még akekor, is, ha a volt alispánt, föszolgabirót, polgármestert vagy jegyzót a tanács alkalmazásában megtartotta.

${ }^{44}$ Boтоs, A Belügyminisztérium története (cit. n. 29) 12.

45 Forradalmi Kormányzótanács jegyzókeönyv (22.3. 1919) pt. 16; cited from IMRE, Forradalmi Kormányzótanács jegyzőkönyvei (cit. n. 27) 56.

${ }^{46}$ Forradalmi Kormányzótanács VI. sz. rendelete. Belügyi Közlöny 17 (30. 3. 1919) 670. Nincsenek továbbá oly címek sem, amelyek csupán hivatali rangviszonyt fejeznek ki (pl. államtitkár, ministeri tanácsos, titkár stb.) [...] A közalkalmazottak azt a bivatali
} 
hierarchy of rank and prestige, in which each rank was associated with a specific social status and privileges. It was a step further in the reform of the administrative personnel (státuszrrendezés) initiated in January 1919 by the People's Republic, which put the administration on a new basis of equality and democratization ${ }^{47}$.

Remuneration was another issue addressed by the overall reform programme of the Soviet Republic. The new legislation, which came into effect on May 3, categorized all civil servants into three classes (rather than the former eleven ranks) according to their qualification and duties, with raises every three years according to seniority. Because of the still-galloping inflation, salaries were paid weekly. Legal differences between civil servants, private employees, and workers were abolished, following the principle that everybody who earns his living by working is to be considered a worker ${ }^{48}$, so that only competence and seniority could justify any difference in remuneration - yet it remains difficult to know to what extent this reform was really applied.

Major changes also occurred at the level of the ministerial personnel. Of the 162 civil servants working in the Commissariat of the Interior, one half (83) were retained from the former ministry ${ }^{49}$. Indeed, a whole new political class stepped in, as political considerations invaded the administration: the presidential department was entrusted to Jenő Kalmár, while the Commissariat was led by Jenő Landler, a former lawyer and Social Democratic leader, together with Béla Vágó, a journalist who had joined the Communist Party in November 1918. The other half of the civil servants (79) arrived gradually during the new regime ${ }^{51}$. These newcomers took their places mostly in the new departments created after the fall of the monarchy: 36 in the political Investigative Department, 15 in the Police Department, 14 in the one devoted to refugee civil servants, plus eight in the old legal department preparing decrees. The arrival of this new personnel thus illustrates the political pressure on the bureaucracy - administration was subjected to the Communist Party and its agenda. But if we consider those who left the administration, we see that out of the 135 civil servants serving in 1918, only two-thirds are to be found in the Commissariat in the spring of

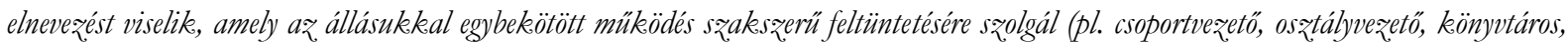
iiögépkezelón stb.).

${ }^{47}$ Like in the case of previous restructuration, this process certainly encountered criticism and opposition from some civil servants, especially regarding the abolition of their prestigious titles. Certainly, memoirs of high ranking officials can enlighten their reactions, especially if they were written after the fall of the Soviet regime.

${ }^{48}$ Forradalmi Kormányzótanács LXXXIII. sz. rendelete. Belügyi Közlöny 23 (11. 5. 1919) 876. Mindenkit, aki munkája után él, munkásnak tekint és eltörli azt a megkülönböztetést, amely korábban tisztviselök és más alkalmazottak között fennállott.

${ }^{49}$ Botos, A Belügyminisztérium története (cit. n. 29) 13.

${ }^{51}$ Bотоs, A Belügyminisztérium története (cit. n. 29) 13.
} 
1919, which gives us a glimpse at the scale of political purges that occurred in the central $\operatorname{administration}^{52}$.

In order to ensure the smooth flow of administrative business, threatened by the revolution, the reforms and the increasing work it created, the Soviet Republic had to take pragmatic resolutions regarding work discipline. Working hours were dramatically extended (from 8.30 a.m. to 7 p.m.), and every case had to be addressed within three days ${ }^{53}$. A drastic increase in backlogged paperwork had indeed become a problematic issue since the People's Republic. By the end of November 1918, the Minister of the Interior Batthyány had already introduced three extra hours daily as well as a monthly tally of unresolved cases - a measure which appears not to have been effective enough, as in February 1919, further instructions were given to reinforce work discipline ${ }^{54}$.

During its short existence, the Soviet Republic was able to at last partially reshape the hierarchy of the ministerial personnel and appoint a new guard of civil servants, to restructure the internal organization of the former ministry and to redefine bureaucratic practices, at a time when the crises the previous regime had faced were far from over. Yet the rapidity of these reforms, carried out in a dictatorial manner, could not but face general opposition. Indeed, the communists failed to establish a consensual regime, acceptable to both the population and the Peace Conference, thus leaving the country in a worse situation than ever. According to Mária M. Ormos, "It has to be concluded that the People's Republic, in about five months of existence, proved itself to be unable to lay the foundations of the new Hungarian state, while the verdict on the Soviet Republic must be that it managed to demolish the elements of statehood that were still operating: the public administration, and the law enforcement and judicial system"55.

The counter-revolutionary governments of Arad and Szeged (April to August 1919)

In order to get a full picture of the administration of the Interior and of the political chaos that followed the end of the monarchy, we must also briefly consider the activities of the shadow cabinets: the counter-revolutionary governments of Arad and Szeged. Created at the end of April 1919 by the joint efforts of conservative Hungarians and the French army occupying southern

\footnotetext{
52 The situation of the provincial administration was different, as civil servants were elected for a limited mandate rather than appointed. Yet we can add that by March 23, all government commissioners delegated to the counties were removed and replaced by the directorates, and by March 28, workers' councils headed the capital's municipal administration: Vörös Újság (23. 3., 27. 3., 28. 3. 1919).

53 Bотоs, A Belügyminisztérium története (cit. n. 29) 14.

${ }^{54}$ Ibid. 11. See also MNL OL, K 148, 9892/1918 eln and 2660/1919 eln.

55 Mária Ormos, Hungary in the Age of the Two World Wars, 1914-1945 (New York 2007) 44.
} 
regions of the country, the first - and merely symbolic - counter-revolutionary government aimed at representing the legitimate power against the communists and the revolutionary capital. It was led by the lord-lieutenant of Arad county, Gyula Károlyi, and received the support of the Antibolshevik Committee (A.B.C.), another shadow cabinet formed in Vienna, until its dissolution at the end of May. The Arad counter-government, however, was faced with the opposition of the Romanian occupation forces, which eventually held its members hostage for two weeks. At the end of May it moved to Szeged in the French occupation zone. Only there could it emerge as a political actor, relying on a minimal but still existent administration. Ministerial cabinets were formed, recruiting among local and refugee civil servants, and others who had fled from Budapest. By May 31, the ministers had pledged their formal oath in the traditional forms of the monarchy ${ }^{56}$, and a Ministry of the Interior led by Béla Kelemen began working. Proceeding on the assumption that the occupied regions would soon be reintegrated, he started to reorganize the administration, appointing lord-lieutenants and reforming the police and gendarmerie. Inspired by counterrevolutionary and conservative ideals, his objective was not to reform or renew the administrative practices, but to preserve the legal continuity of the monarchy. The structure of the ministry progressively developed and by mid-June it was composed of a presidential department and five others for general administration, political intelligence, police, border police and gendarmerie respectively. By July, the departments of police and of political intelligence were making daily reports attesting their actual activity. However, the ministry personnel never exceeded 24 officials ${ }^{57}$. The ministry in Szeged of course had no interaction with the People's Commissariat, yet it is hard to imagine that its very existence did not shake the legitimacy of the Revolutionary Governing Council among former ministerial civil servants. Many officials of the Budapest administration who had not been dismissed displayed a notable proclivity to ask for leaves or to report sick, avoiding committing themselves to a regime that was not meant to last ${ }^{58}$. Excepting a few, they did not leave the capital to serve in the counter-revolutionary government, and most of the civil servants on duty in Szeged were transferred from the nearby border police office, border control having been taken under the control of the ministry. Still, some officials like the secretary István Dajkovits and the

\footnotetext{
${ }^{56}$ Béla KELEMEN, Adatok a szegedi ellenforradalom és a szegedi kormány történetéhez [Contribution to the History of the Szeged Counter-revolutionary Government] (Szeged 1923) 200.

${ }^{57}$ BOTOS, A Belügyminisztérium története (cit. n. 29) 22. Their names are to be found in KeLEMEN, Adatok (cit. n. 43) 207.

58 Personnel records dating from the Soviet Republic attest this tendency, as do retrospective sources such as the interrogations conducted during the political purges of the Horthy regime (see below). Therefore, being mentioned in the personnel registers is not a proof that individuals actually worked in the Commissariat, which complicates the reconstitution of the personnel.
} 
sheriff Gyula Korossy, both from the nearby district of Versecz, were recruited from among county administrators, and others like the ministerial concept assistants Gyula Kovacsics ${ }^{59}$ and Andor Siket came from the capital. Although composed of professional civil servants, the Ministry of the Interior in Szeged relied mostly on local officials, who eventually returned to their former offices after the dissolution of the Soviet Republic. Except for Kovacsics, none of them is to be found in the Ministry of the Interior according to the Official Directory (Tišti Cimtár) of 1927. On the contrary, the exiled political class returned to the capital and formed the core of the counterrevolutionary regime under Horthy, Bethlen, and Gömbös, placing themselves in the continuity of the shadow cabinets.

Political vacuum and reconstruction of the Ministry of the Interior (August to December 1919)

On August 1, 1919, the Revolutionary Governing Council resigned and a government of Social Democratic and trade-union leaders headed by Gyula Peidl took charge, soon overthrown by Romanian forces, which entered Budapest three days later. Until 1920, no stable political regime emerged, and ministerial turnover lasted until the consolidation of István Bethlen's government ${ }^{60}$. Powerless governments led to a political vacuum unable to face the multiple crises, in the midst of which the activities of the Ministry of the Interior are difficult to trace.

The most urgent task was dismantling the Soviet administration and resuming the legitimate course of events. The second decree of the Peidl government insisted on preserving legal continuity, which can be illustrated by the continuity of the administrative personnel: almost the whole Konzeptsdienst (fogalmazói szak) of the Ministry of the Interior remained in service ${ }^{61}$. The ministerial administration returned to its former departmental structure, and by mid-August, it was again composed of a presidential department and a further sixteen autonomous departments. The administrative records

\footnotetext{
${ }^{59}$ Kovacsics had worked for the ministerial administration since 1917 but was sent to the county of Temes (where he was born in 1895) as lord-lieutenant's secretary. Before that, he had served as a clerk in the mayor's office of Arad, where the first counter-revolutionary government was formed. Professional and personal ties link him to the Szeged government. By the summer of 1919, he returned to Budapest and continued his career in the Ministry of the Interior until the 1930 s.

${ }^{60}$ Until 1922 and the consolidation of the Bethlen regime, 12 Ministers of the Interior succeeded one another, lasting from a few days (Károly Peyer in the Peidl government, August 1-6, 1919, or Adolf Samassa in the first Friedrich government, August 6-15, 1919) to a few months (Gyula Ferdinandy, July 19, 1920 - February 19, 1921).

${ }^{61}$ BOTOS, A Belügyminisztérium története (cit. n. 29) 29.
} 
of the Szeged government, after its self-dissolution on August 19, were taken over by the new government, in order to materialize the legal continuity ${ }^{62}$.

De facto, however, the new regime (the People's Republic became the Hungarian Republic on August 4) suspended all measures taken by the Soviet Republic regarding administrative personnel. All officials dismissed for political reasons during the communist regime were to be reactivated ${ }^{63}$, and the Home Affairs Bulletin published a general call (felhivás) to all revoked, dismissed or laid-off civil servants, exhorting them to present themselves forthwith to their former offices without further notification ${ }^{64}$. By August 8, the Friedrich government (which served August 6-15) suspended the activities of all provincial councils and reintroduced the counties and municipalities with their former personnel of October 1918 - that is, before the People's Republic, which was thus assimilated to the Soviet regime: All individuals who were serving on October 30, 1918, in the aforementioned institutions, may they have been elected or appointed, are to resume their duties forthwith, with the exception of those who bave since reached the age of retirement or been suspended after disciplinary procedure or prosecution ${ }^{65}$.

Moreover, Minister of the Interior Zsigmond Perényi (served August 15-27, 1919) abrogated the categorization into three classes introduced in March by Béla Kun, as well as every decree promulgated by the Soviet Republic [...] concerning civil servants' wages ${ }^{66}$. All promotions and salary increases were regarded as null and void, and the former legislation in force before March 21 was reinstated

\footnotetext{
${ }^{62}$ In contrast, a rupture can be remarked in the official records regarding the Soviet Republic. Whereas the archival fund K 148 contains all ministerial records from the period 1867-1944, showing a willingness to assert the continuity between the monarchy and the regency, the archives of the Soviet Republic are kept apart. Moreover, the Corpus Juris Hungarici does not include the laws enacted during those months, nor the Collection of Decrees (Rendeletele Tára) the communist ordinances and decrees. Furthermore, the minutes of the Revolutionary Governing Council were also published separately and were not later integrated into the digital version of the ministerial minutes. Only the official organ of the Interior Ministry, the Home Affairs Bulletin (Belïgyi Közlöny), continued every week to publish the laws and decrees enacted during the Soviet Republic. This made the interruption in the constitutional order even more visible than in the case of the neo-absolutist era during the previous century.
}

${ }^{63}$ Minisztertanácsi jegyzókönyv (3. 8. 1919) pt. 11.

${ }^{64}$ Beliigyi Közlöny 39 (17. 8. 1919) 1191. A magyar kormány felszólitja mindazon nem politikai állást betöltö köz̃tisztviselöket és egyéb közhivatali alkalmazottakat, akiket a tanácskormány rendelkezési állományba belyezett vagy müködésïkben más módon megakadályozott, hogy külön értesités bevárása nélkül hivatalukban haladéktalanul jelentkezzeneke.

65 3886/1919 M. E. számú rendelet. Rendeletele Tára (1919) 628. Mindazok az egyének, akik 1918. évi október bó 30-án akár az emlitett testiuleti szervele tagjaiként, akár választás vagy kinevezés alapján hatósági vagy bivatali jogkört gyakoroltak, kötelesele

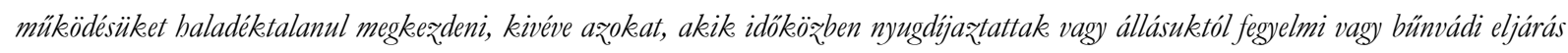
útján felfüggesztettek.

${ }_{60}$ 3988/1919 M. E. számú rendelet. Rendeletek Tára (1919) 639. Mindazok a rendeletek, amelyek a tanácskäztársaság közszolgálati alkalmazottak [...] illetményeivel kapcsolatban kiadattak, tekintet nélkül arra, hogy ezele a. rendeletek a

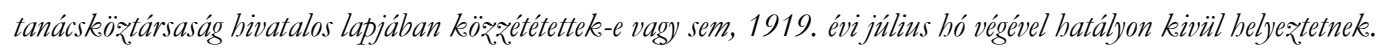


pending a complete reform of the salary system. On September 4, the second Friedrich government (served August 27 - September 11) even decided to revise every appointment made since the People's Republic, thus inaugurating the political purges which would be conducted until $1925^{68}$. Commissions led by the longest-serving secretary of state were formed in each ministry ${ }^{69}$, which would eventually start working after the return to the constitutional order. Moreover, on September 17, the Council of Ministers decided to define a common legal framework to avoid various administrative branches acting differently during the revision procedure amidst the general improvisation ${ }^{70}$. Indeed, overcoming the revolutionary legacy of both republics presented a real challenge: were the purges to be conducted only against those appointed by the Soviet Republic, or were the nominations made by Károlyi also to be reviewed? Was the People's Republic to be considered part of the legal continuity of the Hungarian state, or as the first of the illegitimate revolutions? a political and subsequently a historical issue which would long influence Hungarian historiography ${ }^{71}$. The final decision was first to dismiss without any financial compensation all civil

68 Miniştertanácsi jegyzókönyv (4. 9. 1919) pt. 3. As no research was undertaken on these particular purges, it is yet impossible to quantify their extend. All the more as staff reduction policies carried on during the Bethlen era had also a political dimension. Gergely Ferenc argues for example that the jewish intelligentsia was the first victim of the staff reduction, rising the question of both the antisemitism of the conservative regime and the affiliation of certain Jew to the Soviet Republic. Gergely FERENC, A pedagógustársadalom fegyelmezése (1919-1926) [Surveilling the Education, 1919-1926] Újpedagógiai szemle, 2014/9-10, 15-35 21-23.

${ }^{69}$ Minisztertanácsi jegyzókeönyv (6. 9.19199 pt. 13.

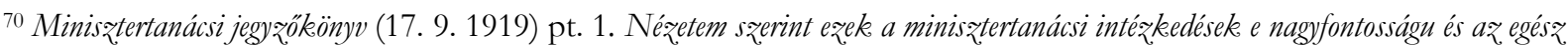
államigazgatás strukturáját mélyen érintō kérdés megoldása szempontjából nem kielégitók, mert a revizió mikénti végrehajtásra vonatkozólag nem nyujtanak utmutatást, s igy arra a nem kivánatos eredményre vez̧ethetnek, különbözó" kormánzati ágaz̧atok a revizió munkáját külöbözóképen fogják végezni. See for example the opposite directives of the Ministry of Cults and Education (4507/1919 V.K.M. számú rendelet) and of the Ministry of Alimentation (6851/1919 K[özélelmezési]. M. számú rendelet).

71 One of Hungarian long-lasting historical legends is the alleged tranfer of power from Mihály Károlyi to the commmunists on March 21, 1919 leading to the proclamation of the Soviet Republic. In the collective imagination, Károyi, the "Red Count", even came to embody the figure of the traitor (the negative counterpart of the "saviour of the fatherland" according to Raoul Girardet's categorization of collective myths). Ignác RoMSICS, "A történetírás objektivitásának mítoszáról és a múlt mitizálásának elfogadhatatlanságáról” [The Myths of Historical Objectivity and the Inadmissibility of Past's Mythification] In: Mítoszok, legendák, tévbitek a 20. századi magyar történelemról [Myths, Legends and False Beliefs About the Hungarian History of the 20th Century ] (Budapest, 2005) 22. The memory of the first Hungarian Republic is indeed ambiguous, condamned by the negative impact of the Soviet Republic during the interwar years, glorified during the communist regime, or contrastingly instrumentalized after the democratic transition - especially after 2012 and the official renaming of the former "Hungarian Republic" as "Hungary". 
servants first appointed during the Soviet Republic ${ }^{72}$, and second to revise the personnel status reform (státusærendęés) initiated by Károlyi, as such anomalies occurred within the status reorganization, which are to cease in order to guarantee the proper course of administration and to preserve the independence of civil service ${ }^{73}$. Moreover, the Minister of Finance, who also supported this decision, asked to suspend further appointments considering present difficulties: Considering the country's financial situation, considering also that we can neither support the civil servants remaining in occupied regions nor provide for refugee civil servants fleeing to us, considering finally that the appointments made by the Károlyi government put a considerable and almost unbearable weight on the nation, I would like to ask not to proceed to any appointment until further notification ${ }^{74}$. It was amidst political chaos that these measures were decided, prompting us to question their effectiveness. Romanian forces invaded the north of Transdanubia while the French army occupied the southern regions. The regency was temporarily entrusted to Archduke Joseph, to whom the legitimist army formed by the Antibolshevik Committee pledged allegiance on August 6. This situation changed as soon as August 23, as the Allies did not wish to see another Habsburg at the head of the country. Meanwhile, the former Minister of Defence in the Szeged government, Admiral Horthy, assembled an informal army and started to reconquer the country as supreme commandant, but with no legal mandate, being confirmed in his duties by the regent on August 13. Foreign occupation, political confusion, the arbitrary exactions of the White Terror following the Red Terror, all led to a national anarchy, which also irritated the delegates at the Peace Conference. According to Mária M. Ormos, who again evaluated the situation concisely and accurately, "This left a country hard to discern at all, with two self-appointed governments [Peidl and Friedrich], an arbitrarily appointed person (Archduke Joseph) in charge of a legally non-existent authority (the regency), but without a constitution, a legislature, a police force, a gendarmerie, or even an army at the government's disposal" ${ }^{27}$. Yet in this moment when the legal existence of the country was suspended, administrative procedures relying on an old guard of professional civil servants were able to ensure a progressive return to the status quo ante - as an illustration of Otto Meyer's dictum: "Verfassungsrecht vergeht, Verwaltungsrecht besteht"”7 .

\footnotetext{
${ }^{72}$ Minisztertanácsi jegyzőkönyv (17. 9. 1919) pt. 38.

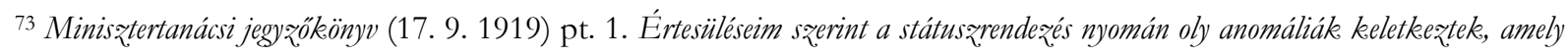
a közigazgatás rendes menetének biztositása és a szolgálati függelem megszilárditása érdekében okvetlenül megszüntetendök.

${ }^{74}$ Minisżtertanácsi jegyzőkönyv (17. 9. 1919) pt. 38. Egyben tekintettel az ország pénzürgyi helyzetére, tekintettel továbbá arra, hogy a megszállott területeken tartozkodó közszolgálatialkalmazottakat nem tudjuk támogatni és a hozzánk menekült közszolgálati alkalmazottakat sem tudjuk kellöképen ellátni, tekintettel továbbá arra, hogy a Károlyi kormány alatt esžközölt kinevezések is sz̨inte elviselhetetlen terhet rónak az országra, tisztelettel kérem annak kimondását is, hogy további intézkedésig új állások nem rendszeresithetök. 75 Ormos, Hungary (cit. n. 42) 61.

${ }^{76}$ Otto MAYER, Deutsches Verwaltungsrecht, 1 (München ${ }^{31924), ~ u n p a g i n a t e d ~ f o r e w o r d . ~}$
} 
Resurgence of the royal Ministry of the Interior

In January 1920, the Smallholders' Party and the Christian National Union Party won the elections and by March, Horthy was elected as regent. Yet the Horthy regime, whose durability allowed the administration to be re-established on a stable basis, inherited the unsolved structural problems of the Dualist administration along with the short-term ones created by the war and the revolutions. It was called on to carry out the political purges decided by the temporary governments, to deal with the so-called "civil service question" (tisztviselöi kérdés) brought on by the overflow of administrative personnel in the reduced country, and simultaneously to provide for refugee civil servants. Meanwhile, it had to finalize the general reform of the administration, define new systems of qualification, formation, recruitment and remuneration of the personnel, and achieve the rationalization, centralization and deconstruction of the state apparatus.

In the conduct of political purges, the new regime adopted the principles formulated by the previous governments. However, we can observe an evolution since the summer of 1919, in the sense that measures taken against civil servants appointed during the Károlyi Republic were reinforced. Indeed, the decision to dismiss any official who was first appointed during the People's Republic was inscribed in law 11/1920: All civil servants and employees of the state, county or railway administration appointed to any office or function since October 31, 1918, and who were not in the service of the state, county or railway administration directly before this appointment, are to be dismissed at the promulgation of the present law, by the end of July 1920 at the latest. Such employees have no right to claim any subsidy or remuneration from the Treasury ${ }^{77}$.

Moreover, Law 11/1920 also offered the possibility of reviewing any transfers or promotions made since October 31, 1918, and possibly revoking them (\$2), which had never been a question before. Besides, the ideological framework of the political purges was defined for the first time: civil servants who had displayed antipatriotic, antisocial behaviour or acted against public morals since October 31, yet whose actions were not severe enough to justify their dismissal, could now be removed at the discretion of the minister $(\$ 4)$. With this provision, the basic irrevocability of civil servants was suspended, and the vague definition of "antipatriotic" behaviour opened the way to ideological

\footnotetext{
${ }^{77}$ Law 11/1920, S 3. Mindazokat az állami, államvasuti és vármegyei tisztviselóket és egyéb alkalmazottakat, akik az 1918. évi október bó 31.-ike óta nevętettek ki bármilyen állásra, vagy alkalmaztattak bármilyen minöségben, és akik ezt a kineveztetésüket vagy alkalmaz̧tatásukat közvetlenül megelózöleg állami, államvasuti vagy vármegyei alkalmazásban nem állottak, a jelen törvény hatálybalépése után azonnal, de legkésöbb 1920. évi július hó végével el kell bocsátani s az ilyen alkalmazottak az államkincstárral szemben ebböl az. alkalmazásukból kifolyólag semmiféle ellátásra sem tarthatnak igényt.
} 
considerations. The government itself opposed abusive arrests by simple denunciation, yet the Ministers of the Interior and of Defence defended the procedure, arguing that the communist threat was not over ${ }^{78}$. Besides the review commissions (igazoló bizottság) instituted by the Friedrich government in September, disciplinary commissions (fegyelmi bizottság) were thus created ad hoc in each ministry to conduct interrogations within the framework of a broad investigation of civil servants' behaviour since the end of the monarchy ${ }^{79}$. In the case of the Ministry of the Interior, the archives keep records of these interrogations, whose results civil servants were required to present to their superiors with the set formula I hereby present to you the decision regarding my bebaviour during the so-called Soviet Republic ${ }^{80}$. In addition, denunciations could lead to a disciplinary investigation, which could last several months or years, and during which individuals received only part of their wages, could not be promoted, but were also not allowed to leave public service. Still, not much can be reported on these investigations, as no historical study has yet been devoted to the subject ${ }^{81}$.

But political purges form only one aspect of the general trend that reshaped the administrative corps after the end of the monarchy. Like other European states, Hungary had to institute a rigorous policy of staff reduction to face the economic crisis: in this regard, war indeed acted as a catalyst and not merely as a short-term stimulus for reform. In France, though a victorious country, drastic reductions were carried out by the High Investigation Committee led by Maurice Bloch, who in 1922 proposed the suppression of 50,000 public offices, and "administrative deflation" was pursued throughout the $1930 \mathrm{~s}^{82}$. In Austria too, the new republic had to reduce the number of

\footnotetext{
78 Minisztertanácsi jegyzőkönyv (2. 12. 1919) pt. 12.

${ }^{79}$ MNL OL, K 148, 1920-5.t. 29-96 am/I 383-435 oldal.

${ }^{80}$ MNL OL, K 148, 728 cs. 8 oldal. Az ugynevezett Tanácsköztársaság ideje alat tanusitott magatartásomra vonatkozó határozatot tiştelettel bemutatom.

${ }^{81}$ Unfortunately, the archives barely retain any records on civil servants who were dismissed. Still, some "affairs" are to be found, for example, the case of Adjunct Secretary of State and director of the National Archives Dezső Csánky, denounced by a subordinate but later discharged: MNL OL, K 148, 1920-5.t. 29-96 am/I (368) 10-140 oldal. Or that of István Fuchs, employee of the Interior and strong advocate of the communist regime, who was actually arrested and never returned to the administration: MNL OL, K 148, 1920-5.t. 29-96 am/I (368) 315 oldal. The historical value of these records is to be highlighted, as they not only illuminate the modalities of the political purges by the counterrevolutionary regime, but also shed some light on the everyday life in the offices of the Soviet Republic, which would otherwise remain a blind spot. A critical perspective on these records is of course fundamental, as they provide us an a posteriori reconstruction of the period, in an effort to distance the creators from any communist sympathies; in fact, the ideological condemnation of the Soviet Republic is so omnipresent we can hardly forget it was their very purpose. ${ }^{82}$ Émilien RuIZ, Trop de fonctionnaires? Contribution à une histoire de l'État par ses effectifs 1850-1950 (Paris 2014) 333-368. See also Pierre Rosanvallon, L'État en France de 1789 à nos jours (Paris 1990). Rosanvallon explains how,
} 
personnel in public administration under direct pressure from the League of Nations starting in $1922^{83}$. In Hungary, territorial losses and the massive arrival of refugee civil servants seeking posts made the issue even more urgent. According to Minister of Finance Loránt Hegedús, who gave an interview to the daily paper Pesti Hirlap in February 1921, it became generally acknowledged that our administration could be carried out with only a third of the civil servants ${ }^{84}$. Secretary of State for the Interior István Weis asserted the same in December 1919: Already during peacetime, the number of civil servants was about three times higher here than we needed to maintain the administration. Kálmán Tisqa, with good intentions but in fact incredibly unfortunately, wished to save the middle class by leading their sons into an administrative career, and thereby multiplied offices for which there was no real need ${ }^{85}$. The personnel policy of former Prime Minister Tisza during the Dualist era was indeed constantly criticized as having offered shelter to the penniless gentry, a widely held view which also influenced Hungarian historiography until the end of the 20 th century ${ }^{86}$.

Although its necessity was generally acknowledged, staff reduction policy was progressively implemented during the first years of the Horthy regime. The ministerial council had already decided on September 17, 1919, to freeze all further promotions or nominations. Political purges were also clearly acknowledged as a solution, as every opportunity must be seized to reduce the number of

even in a victorious country such as France which did not face the same political turmoil as successor states, the "ordeal of war" led to "a profound reflexion on the state's structures": ibid. 232s.

${ }^{83}$ See the contributions by Gertrude Enderle-Burcel and by Karl Magner in this volume. Staff reduction policy is also ${ }^{84}$ Loránt Hegedûs interviewed in Pesti Hirlap (15. 2. 1921). Altalános meggyózódéssé vált, hogy állami adminisztrációnkt a tisztviselök egyharmadával el lehetett volna végezni.

${ }^{85}$ István WEIS, Tisztviselők válsága [Civil Servants’ Crisis]. Magyar Köztiştviselók Lapja (31. 12. 1919). Nálunk már béke idején is kb. háromszor annyi volt a köztisztviselök száma, mint amennyi el tudta volna látni a közszüleségletet. Tisza Kálmán jószándékbból, de hihetetlenül sz̧erencsétlen kézzel úgy akarta megmenteni a középosztályt, hogy fiait tisztviselö pályára terelte és derüreborúra állitotta fel tényeleges szüleséglet nélkeül az állásokat.

${ }^{86}$ For Otto Szabolcs, for example, it was this very sociological and political background that determined civil servants to form the social base of the conservative Horthy regime: Otto SZABOLCS, Köztisztviselők az ellenforradalmi rendszer társadalmi bázisában, 1920-1926 [Civil Servants in the Social Basis of the Counter-revolutionary Regime, 1920-1926] (Budapest 1965) 210. However, more recent research tends to downplay the importance of the gentry in the Dualist administration. See e. g. Endre NAGY, A dzsentroid hivatalnok a Monarchia korában. Tézisszerűségek egy hipotézisről [The Gentroid Civil Servant During the Monarchy. Somes Thesis on a Hypothesis] (Salgótarján 1981) 147-162; Gábor BENEDEK, Dzsentri és Bach-huszár. Társadalomtörténeti vizsgálatok a neoabszolutizmus- és a dualizmuskori tisztviselőkről [Gentry and Bach-Hussars. Social History of Civil Servants During the Neoabsolutism and the Dualist Era] (Budapest 1997) 223. 
civil servants ${ }^{87}$, according to the Finance Minister; yet in fact, a general promotion was accorded in the Ministry of the Interior as soon as March 1920, allegedly to reward the valuable services of civil servants during these hard times ${ }^{88}$. The first substantial reduction was achieved in 1922, when 61 offices out of 892 were suppressed in the Interior according to the budget defined in Law 1/1922. In April 1923, another instruction ordered a general diminution of $20 \%$ of all offices, which was eventually carried out by means of severance payments and forced retirements ${ }^{89}$. These massive layoffs were barely finished when Law 4/1924 demanded another reduction by $12 \%$. By the mid-1930s, more than a third of all the civil servants of the Interior (including the Konzeptsdienst, but also the accounting and auxiliary offices) had been dismissed, their numbers falling from 892 individuals in 1920 to only 566 in 1934 . These cuts were not limited to the central institutions - administrative offices across the country were affected as well. In 1922, under the system of the so-called B-lists, 11,126 state employees were dismissed, among them 4,377 civil servants, 3,616 teachers, and 2,918 auxiliary employees ${ }^{90}$. Laws $1 / 1922, \sqrt{ } 24$, and $6 / 1922, \sqrt{ } 3$, had mandated the creation of lists of "supernumerary" and "superfluous" civil servants in every administrative branch, who were later to be dismissed - most of the time within 8 days after notification. These were the B-lists, as opposed to the A-list comprehending those whose post was not threatened. Yet, at least according to Otto Szabolcs, staff reductions were not applied as provided by the law, and it was rather the ones "who managed to cope with the communist commissions" who were dismissed. The following year, the second B-list led to 14,813 dismissals out of the 203,000 state employees in the country. Ironically, these staff reductions were conducted simultaneously with the massive reintegration of refugee civil servants into both the ministerial and the county administration - a phenomenon which is still difficult to quantify given the lack of research on the matter. According to the official records of the National Office for Refugees Affairs (Orşágos Menekültügyi Hivatal, $\mathrm{OMH}$ ) created in 1920 to coordinate refugees arriving from successor states and to take care of their lodgement and boarding, more than 350,000 people returned to Hungary between 1920 and 1924, among whom civil servants formed the most numerous socio-professional group ${ }^{91}$. After

\footnotetext{
${ }^{87}$ Minis そৃtertanácsi jegyzőkönyv (17. 9. 1919) pt. 38. Részemről szükségesnek tartom, hogy ez a kérdés általánosságban szabályoztassék annál is inkább, mert a közszolgálat körében amugy is tulságosan sok alkalmazott van elhelyezve, s ennélfogva minden alkalmat fel kell használni arra, hogy a közszolgálati alkalmazottak száma apasztassék.

8817 Konzeptsbeamten were promoted and given the title and character of the upper rank: Minisztertanácsi jegyzökönyv (14. 3. 1920) pt. 12.

${ }^{89}$ Minisz̨tertanácsi jegyzőöönyv (20. 4. 1923) pt. 1.

${ }^{90}$ SzABOLCS, Köztisztviselők (cit. n. 70) 85s.

${ }^{91}$ New estimations have even revised these figures upwards to 420-425,000 refugees after the First World War, as the $\mathrm{OMH}$ did not take into account those who arrived before the peace treaty nor illegal refugees. Even before the formal
} 
October 1, 1920, Prime Minister István Bethlen, who headed the OMH, even proposed to forbid any new arrivals ${ }^{92}$. This long-term process lasted well into the post-war years and became Hungary's foremost social issue, manifesting the retreat of a Hungarian administration meticulously set up during the previous decades following a policy of modernization and magyarization. Refugee civil servants living with their families in carriages at railway stations became a symbol of the "tragedy of Trianon" ${ }^{\prime 93}$.

It thus took five years for the counter-revolutionary government to achieve administrative deflation, eventually at the cost of a general discontent and declining status of its very social base. Indeed, even if some dismissed civil servants were reactivated, retrained, or accorded retirement pensions, which is why only a few of them are to be found among the unemployment statistics of 1928, the overburdened public service no longer represented an attractive vocation. However well preserved the ministerial administration may have remained, especially in the upper ranks of the hierarchy, downsizing would eventually affect senior officials too. Indeed, the number of civil servants in the second to fifth ranks first rose from 24 to 31 between 1920 and 1925, but then fell to 19 after the economic crisis in $1929^{94}$. Staff reductions also meant additional workload for the remaining officials, at a time of increasing paperwork: in 1919, 127,571 action files were created in the Ministry of the Interior, but this figure rose to 336,756 by 1925 and even 585,320 in $1935^{95}$, representing a fivefold increase even as the staff was reduced by a third. Work discipline, already tightened during both republics, became even more severe, and rationalization of the procedures resulted almost of its own accord from the economic constraints (proving once again the validity of Parkinson's Law). Since August 1920, each ministry had to prepare monthly reports of its activities, showing the exact amount of unresolved paperwork, leading to further ministerial

handover of power enacted by the peace treaty, what was considered as a foreign occupation drove thousands of refugees out onto the roads, almost half a million by the latest estimations. According to the OMH's official statistics, 57,000 refugees arrived in the reduced country during the two last months of 1918. Their number doubled in 1919 (110,000 refugees), and by 1920, it reached 121,000 people; see Miklos ZEIDLER, A revíziós gondolat [The Revisionist Thinking] (Budapest 2001) 390. For more information on the OMH, see Emil PETRICHEVICH-HORVÁTH, Az Országos Menekültügyi Hivatal négyéves működéséről [Four Years of National Office for Refugees Affairs] (Budapest, 1924). 92 Minisztertanácsi jegyzőöönyvek (1. 10. 1920) pt. 15. Furthermore, the borders were closed several times, from June 23 to October 31, 1921, and again intermittently since June 1924, to regulate the arrivals.

${ }^{3}$ István Gergely SZƯTS, “Vasutas vagonlakók és a MÁV menekültpolitikája 1918-1924” [Railway Employees Living in Wagons and the National Railways' Refugee Politics 1918-1924] Múltunk 2012/4 89-112.

${ }^{94}$ Bотоs, A Belügyminisztérium története (cit. n. 29) 57.

${ }^{95}$ By this time, the Ministry of Public Welfare and Work had been suppressed because of the economic crisis, and both health and social care had been returned as attributions to the Ministry of the Interior in summer 1932, partially explaining the massive increase of business. 
reprisals and complaints of administrative slowness. In 1927, Minister of the Interior Béla Scitovszky introduced the workbooks reporting the duties of each civil servant and reviewed by the presidential department. On the other hand, in 1922 the lower administrative ranks were cautioned against sending superfluous or simply informative reports, in order to avoid useless paperwork. The following year, the Ministry of the Interior led a governmental commission dedicated to the unification and simplification of all printed forms used in state administration, reflecting the materiality of this rationalization effort.

\section{Conclusion}

The decade spanning the First World War, the emergence of the republic, and the consolidation of the counter-revolutionary regime witnessed the most important transformation of the administration up to then. The policies of centralization pursued during the war and repeated attempts to democratize both recruitment and bureaucratic practice led to major reform projects that reshaped the public service. In order to face the multiple difficulties resulting from the war, the territorial losses and the political reconfiguration, the administration had to be rationalized, modernized, made more efficient - in one word: the continuously postponed reform had to be carried out. Both republics indeed initiated vast reform projects, claiming they would achieve the long-awaited reform and overcome bureaucratism. Behind this criticism of bureaucracy and excessive legal procedures lay the aim of ousting the traditional, legally trained elite of the liberal era and replace it either with a democratic reform or with the dictatorship of the proletariat - which both regimes lacked the time to achieve. Yet relying on the expertise of the old administrative elite, they also carried on the administrative reform planned since the Dualist era, taking on the welfare policies initiated during the war, the moral responsibility for refugee civil servants, and the rationalization of the Interior - a continuity once again materialized in the blue folders passed from one regime to another ${ }^{96}$.

The post-war period thus presents a real cognitive challenge. Despite the continuity, 1918 was unquestionably a turning point and a rupture in constitutional order. This paradox should lead to a paradigm shift, forcing us to abandon the binary opposition of rupture versus continuity and consider the whole complexity of this great transformation. Despite the defeat and the revolutions,

\footnotetext{
${ }^{96}$ It was not until the end of the 1920s that some action files begun under the Soviet Republic were definitely closed; see Bотоs, A Belügyminisztérium története (cit. n. 29) 57. These files inherited from the Soviet Republic (identified by the headers of the blue folders) were deposited in the archives: MNL OL, K 148, 1919-5-366, 1920-36-453, 112 cs, 5642/1919 eln., 6033/1919 eln. and 6086/1919 eln.
} 
which might have permitted making a clean slate of former institutions and practices, the republics failed at achieving the great transformation they announced - which would eventually be carried out in the second half of the 1920s. Although the exceptional situation did act as a catalyst leading to radical restructuring, the general reform civil servants called for was repeatedly postponed due to this very instability. Yet it was also a time of great reflections and projects, initiated by the political class, senior officials, and lawyers' associations ${ }^{97}$. Even if most of them remained just wishful thinking, their influence is not to be minimized.

97 Andor CsIzmadia, A magyar közigazgatás fejlődése a XVIII. századtól a tanácsrendszer létrejöttéig [The Development of the Hungarian Administration from the 18th Century until the Regime of the Soviets] (Budapest 1976) 300-308. 
Annex: Evolution of the Ministry of Interior's internal structure $1918-1922$

\begin{tabular}{|c|c|c|c|c|c|}
\hline \multicolumn{2}{|l|}{$\begin{array}{c}\text { Royal ministry of the Interior: } \\
01.10 .1918\end{array}$} & \multicolumn{2}{|c|}{$\begin{array}{c}\text { Commissariat of the Interior: } \\
01.04 .1919\end{array}$} & \multicolumn{2}{|c|}{$\begin{array}{l}\text { Commissariat of the Interior: } \\
\text { (project) 01.08.1919 }\end{array}$} \\
\hline \multicolumn{2}{|l|}{ Minister } & \multicolumn{2}{|l|}{ Commissar } & \multicolumn{2}{|l|}{ Commissar } \\
\hline \multicolumn{2}{|l|}{ State secretaries } & \multicolumn{2}{|l|}{ Vice-commissar } & \multicolumn{2}{|l|}{ Vice-commissar } \\
\hline Presidential department & 1 & \multirow{3}{*}{ I. Presidential department } & \multirow{3}{*}{1} & \multirow{2}{*}{$\begin{array}{l}\text { I. Task group: general } \\
\text { administration }\end{array}$} & \\
\hline Presidential sub-department & 1 & & & & \\
\hline Military exemptions & 2 & & & \multirow{2}{*}{ A/ Sub-task group: } & \\
\hline Translation department & 3 & \multirow{3}{*}{$\begin{array}{l}\text { II. Department of legal } \\
\text { codification }\end{array}$} & \multirow{3}{*}{4} & & \\
\hline I. Department of legal codification & 4 & & & \multirow[b]{2}{*}{ 1. Presidential department } & \multirow[b]{2}{*}{1} \\
\hline $\begin{array}{l}\text { II. Public law and communal } \\
\text { residence }\end{array}$ & \multirow{3}{*}{5} & & & & \\
\hline a/ Public law & & \multirow{3}{*}{ III. Press department } & \multirow{3}{*}{$(\mathrm{X})$} & \multirow{2}{*}{ 2. Exemption department } & \multirow{2}{*}{2} \\
\hline b/ Communal residence & & & & & \\
\hline III. County department & 6 & & & 3 Public law & 5 \\
\hline IV. Municipality department & \multirow{3}{*}{7} & & & 3. Public law & כ \\
\hline a/ Municipal administration & & IV Elections denartment & (X) & 4. Informative & \\
\hline $\begin{array}{l}\text { b/ Municipal budget and city } \\
\text { development }\end{array}$ & & 1 V. Liections cepartintent & $(\Lambda)$ & and complains & 21 \\
\hline $\begin{array}{l}\text { V. Communal and state register } \\
\text { department* }\end{array}$ & & V. Political detective & & 5. Infraction and justice & 12 \\
\hline a/ Communal administration & $8 ; 9$ & department & $(\mathrm{X})$ & & \\
\hline b/ Communal budget & & & & 6. Accounting office & \\
\hline VI. Police department & 10 & & & o. Accounung once & \\
\hline a/ Public security & & VI. Public law & 5 & 7. Auxiliary office & \\
\hline $\mathrm{b} /$ Gendarmerie & $10 / 2$ & & & 1. Muxinary onnce & \\
\hline c/ Police border & $10 / 3$ & & & & \\
\hline VII. State order & 11 & VII. County department & 6 & B/ Sub-task group: & \\
\hline VIII. Police penal department & 12 & & & 1. State register and name & 0 \\
\hline IX. Public health department* & 3 & & & change & y \\
\hline a/ General health & 13 & VIII. Municipality department & 7 & 2. Public assistance and & $15 \cdot 20$ \\
\hline $\mathrm{b} /$ Pharmaceutic and nursing & & & & refugees & (20 15,20 \\
\hline X. Public health administration & & & & & \\
\hline $\begin{array}{l}\text { a/ Public health legal } \\
\text { codification }\end{array}$ & 13 & municipal civil servants & $7 ; 20$ & 3. Provincial civil servants & 20 \\
\hline b/ Public health administration & & & & 4. Public order & 11 \\
\hline XI. Department of family services & 14 & & & 4. Public order & 11 \\
\hline a/ Administration & 14 & X. Refugee communal civil & $8 ; 20$ & II Task oroun administration & $6 \cdot 7 \cdot 8$ \\
\hline b/ Guardianship & & & & 11. 1 ask group: admInIIstration & $0 ; 1 ; 0$ \\
\hline $\begin{array}{l}\text { XII. Public assistance and social } \\
\text { department* }\end{array}$ & 15 & & & A/ Sub-task group: council & 6 \\
\hline a/ Warfare assistance & & XI. Police penal department & $10 ; 12$ & adi & \\
\hline b/ Philanthropic actions & & & & B/ Sub-task group: & \\
\hline c/ Social assistance & & & & administrative organisation & $0 ; / 8$ \\
\hline XIII. Department of immigration & & XII Public assistance & 15 & & \\
\hline $\begin{array}{l}\text { a/ Immigration administration } \\
\text { and passport }\end{array}$ & 16 & XI1. Public assistance & 15 & III. Task group: Public order & 10 \\
\hline $\mathrm{b} /$ Defence & & & & & \\
\hline $\begin{array}{l}\text { XIV. Child protection } \\
\text { department* }\end{array}$ & 17 & XIII. Passport department & 16 & 1. Passport department & 16 \\
\hline XV. Technical department & 18 & & & & \\
\hline XVI. State register department & 9 & & & 2. Red Army & $(\mathrm{X})$ \\
\hline XVII. Tourism department & 19 & $\begin{array}{l}\text { XIV. State register and name } \\
\text { change }\end{array}$ & 9 & 3. Political detective & $(\mathrm{X})$ \\
\hline Accounting office & & Accounting office & & & \\
\hline Auxiliary office & & Auxiliary office & & & \\
\hline
\end{tabular}

* After the proclamation of the People's Republic on November 1918, these departments were transferred to the Ministry of Public Welfare and Work. Otherwise the internal structure of the Ministry remained merely unaffected by the change of regime. 


\begin{tabular}{|c|c|c|c|c|c|}
\hline \multicolumn{2}{|c|}{$\begin{array}{c}\text { Ministry of the Interior - Szeged: } \\
\text { 01.07.1919 }\end{array}$} & \multicolumn{2}{|l|}{$\begin{array}{l}\text { Ministry of the Interior: } \\
\text { autumn } 1919\end{array}$} & \multicolumn{2}{|l|}{$\begin{array}{c}\text { Ministry of the Interior: } \\
\qquad 14.03 .1920\end{array}$} \\
\hline Minister & & Minister & & Minister & \\
\hline State-secretary & & $\longrightarrow$ State secretaries & 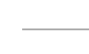 & State secretaries & \\
\hline \multirow{5}{*}{ Presidential department } & \multirow{5}{*}{1} & \multirow{3}{*}{ Presidential department } & \multirow{3}{*}{1} & Presidential department & 1 \\
\hline & & & & Presidential sub-department & 1 \\
\hline & & & & Military exemptions & 2 \\
\hline & & \multirow{2}{*}{ I. Public law } & \multirow{2}{*}{5} & Translation department & 3 \\
\hline & & & & I. Department of legal codification & 4 \\
\hline \multirow{4}{*}{ I. Administrative department } & \multirow{4}{*}{$6 ; 7 ; 8$} & \multirow[t]{2}{*}{ II. Legal codification } & \multirow[t]{2}{*}{4} & $\begin{array}{l}\text { II. Public law and communal } \\
\text { residence }\end{array}$ & \multirow[t]{3}{*}{$5 ; 8$} \\
\hline & & & & a/ Public law & \\
\hline & & \multirow{2}{*}{ III. County department } & \multirow{2}{*}{6} & $\mathrm{~b} /$ Communal residence & \\
\hline & & & & III. County department & \multirow{3}{*}{6} \\
\hline \multirow{4}{*}{$\begin{array}{l}\text { II. Department of political } \\
\text { intelligence }\end{array}$} & \multirow{4}{*}{21} & \multirow{2}{*}{ IV. Municipality department } & \multirow{2}{*}{7} & a/ County administration & \\
\hline & & & & b/ County budget & \\
\hline & & \multirow{2}{*}{ V. Communal department } & \multirow{2}{*}{8} & IV. Municipality department & \multirow{3}{*}{7} \\
\hline & & & & a/ Municipal administration & \\
\hline \multirow{4}{*}{ III. State police department } & \multirow{4}{*}{$10 / 1$} & \multirow[t]{2}{*}{ VI. Police department } & $10 / 1$ & $\begin{array}{l}\text { b/ Municipal budget and city } \\
\text { development }\end{array}$ & \\
\hline & & & & V. Communal department & \\
\hline & & VUI Dolice nenal denortment & 12 & a/ Communal administration & 8 \\
\hline & & vil. ronce penal department & 12 & b/ Communal budget & \\
\hline & & VUU Donortment f ctote ordar & 11 & VI. Police department & $10 / 1$ \\
\hline 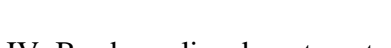 & 100 & Vill. Department of state order & 11 & a/ Public order & 11 \\
\hline IV. Border police department & $10 / 3$ & & 11 & $\mathrm{~b} /$ Gendarmerie & $10 / 2$ \\
\hline & & IX. Department of public order & 11 & c/ Border police & $10 / 3$ \\
\hline & & X Border nolice denartment & $10 / 2$ & VII. Police administration & 10 \\
\hline V Gendarmerie denartment & $10 / 2$ & X. Border police department & $10 / 3$ & VIII. Law enforcement & 10 \\
\hline V. Gendarmerie department & $10 / 2$ & & & IX. Public order and security & \\
\hline & & XI. Public assistance & 15 & a/ Administration of public order & 11 \\
\hline & & XII. Department of family & & $\mathrm{b} /$ Regulation of public order & 11 \\
\hline VI Docinort d & 16 & services & 14 & X. Police penal department & 12 \\
\hline V1. Passport department & 16 & XIII. Department of child & 17 & XI. Department of family services & $14 ; 17$ \\
\hline & & protection & 17 & XII. Public assistance & 15 \\
\hline & & YIV State reqicter & 0 & XIII. Department of immigration & \\
\hline & & XIV. State register & 9 & $\mathrm{a} /$ Immigration and passport & 16 \\
\hline & & & $16 \cdot 10$ & $\mathrm{~b} /$ Defence & \\
\hline & & $X V$. Department of immigration & $16 ; 19$ & XIV. State register department & 9 \\
\hline & & & & XV. Immigration Office & $16 ; 19$ \\
\hline & & Accounting office & & Accounting office & \\
\hline & & Auxiliary office & & Auxiliary office & \\
\hline
\end{tabular}




\begin{tabular}{|c|c|c|c|}
\hline \multicolumn{2}{|c|}{ Ministry of the Interior: 01.06 .1920} & \multicolumn{2}{|c|}{ Royal ministry of the Interior: 01.11 .1922} \\
\hline \multicolumn{2}{|l|}{ Minister } & \multicolumn{2}{|c|}{ Minister } \\
\hline \multicolumn{2}{|l|}{ State secretaries } & \multicolumn{2}{|c|}{ State-secretaries } \\
\hline Presidential department & 1 & Presidential department & 1 \\
\hline I. Public Law & 5 & I. Department of legal codification & 4 \\
\hline II. Legal codification & 4 & II. Public law & 5 \\
\hline III. County department & 6 & III. County department & 6 \\
\hline IV. Municipality department & 7 & IV. Municipality department & 7 \\
\hline V. Communal department & 8 & V. Communal department & 8 \\
\hline VI. State police department & \multirow{3}{*}{10} & VI. Police department & 10 \\
\hline a/ Staff & & a/ State police & \multirow{4}{*}{$\begin{array}{l}10 / 1 \\
10 / 2 \\
10 / 3 \\
10 / 4\end{array}$} \\
\hline b/ Budget & & b/ Gendarmerie & \\
\hline c/ Police & \multirow{2}{*}{$\begin{array}{l}10 / 1 \\
10 / 2\end{array}$} & c/ Gendarmerie (staff) & \\
\hline d/ Gendarmerie & & d/ Fluvial security & \\
\hline VII. Police penal department & 12 & e/ Public order & 11 \\
\hline VIII. Public order and administration & 11 & VII. Public security & 11 \\
\hline IX. Border police & $10 / 3$ & VIII. Police authorization & $10 ; 12$ \\
\hline X. Public assistance & 15 & IX. Administration of public order & 11 \\
\hline XI. Department of family services & 14 & X. Police penal department & 12 \\
\hline XII. Department of child protection & 17 & XI. Department of family services & $14 ; 17$ \\
\hline XIII. State register & 9 & XII. Department of immigration & 16 \\
\hline \multirow[t]{2}{*}{ XIV. Department of immigration } & 16 & XIII. State register & 9 \\
\hline & & XIV. Peace Conference & $(X)$ \\
\hline Accounting office & & \multicolumn{2}{|c|}{ Accounting office } \\
\hline Auxiliary office & & \multicolumn{2}{|c|}{ Auxiliary office } \\
\hline
\end{tabular}

\section{Legend}

1 Presidential department

2 Military exemptions

3 Translation department

4 Legal codification

5 Public Law

6 County administration

7 Municipal administration

8 Communal administration

9 State register

10 Police (1), Gendarmerie (2),

Border police (3), Fluvial security (4)
11 Public order and security

12 Police penal department

13 Public health

14 Family services

15 Public assistance

16 Immigration and passports

17 Child protection

18 Technical department

19 Tourism

20 Refugee civil servants

21 Press and information

(X) Political administration (Soviet Republic) 